\title{
Antibacterial and Anticancer Activity and Untargeted Secondary Metabolite Profiling of Crude Bacterial Endophyte Extracts from Crinum macowanii Baker Leaves
}

\author{
Tendani E. Sebola ${ }^{D},{ }^{1}$ Nkemdinma C. Uche-Okereafor, ${ }^{1}$ Lukhanyo Mekuto, \\ Maya Mellisa Makatini, ${ }^{3}$ Ezekiel Green, ${ }^{1}$ and Vuyo Mavumengwana ${ }^{4}$ \\ ${ }^{1}$ Department of Biotechnology and Food Technology, Faculty of Science, University of Johannesburg, Doornfontein Campus, \\ Johannesburg, South Africa \\ ${ }^{2}$ Department of Chemical Engineering, Faculty of Engineering and the Built Environment, University of Johannesburg, \\ Doornfontein Campus, Johannesburg, South Africa \\ ${ }^{3}$ Molecular Sciences Institute, School of Chemistry, University of the Witwatersrand, Johannesburg, South Africa \\ ${ }^{4}$ DST-NRF Centre of Excellence for Biomedical Tuberculosis Research, \\ South African Medical Research Council Centre for \\ Tuberculosis Research, Division of Molecular Biology and Human Genetics, Faculty of Medicine and Health Sciences, \\ Stellenbosch University, Tygerberg Campus, Cape Town, South Africa \\ Correspondence should be addressed to Tendani E. Sebola; 200905353@student.uj.ac.za
}

Received 15 June 2020; Revised 29 September 2020; Accepted 26 November 2020; Published 10 December 2020

Academic Editor: Karl Drlica

Copyright (@) 2020 Tendani E. Sebola et al. This is an open access article distributed under the Creative Commons Attribution License, which permits unrestricted use, distribution, and reproduction in any medium, provided the original work is properly cited.

\begin{abstract}
This study isolated and identified endophytic bacteria from the leaves of Crinum macowanii and investigated the potential of the bacterial endophyte extracts as antibacterial and anticancer agents and their subsequent secondary metabolites. Ethyl acetate extracts from the endophytes and the leaves (methanol: dichloromethane $(1: 1)$ ) were used for antibacterial activity against selected pathogenic bacterial strains by using the broth microdilution method. The anticancer activity against the U87MG glioblastoma and A549 lung carcinoma cells was determined by the MTS (3-(4,5-dimethylthiazol-2-yl)-5-(3-carboxymethoxy-phenyl)-2-(4-sulfophenyl)-2H-tetrazolium) assay. Bacterial endophytes that were successfully isolated from C. macowanii leaves include Raoultella ornithinolytica, Acinetobacter guillouiae, Pseudomonas sp., Pseudomonas palleroniana, Pseudomonas putida, Bacillus safensis, Enterobacter asburiae, Pseudomonas cichorii, and Arthrobacter pascens. Pseudomonas cichorii exhibited broad antibacterial activity against both Gram-negative and Gram-positive pathogenic bacteria while Arthrobacter pascens displayed the least MIC of $0.0625 \mathrm{mg} / \mathrm{mL}$. Bacillus safensis crude extracts were the only sample that showed notable cell reduction of $50 \%$ against A549 lung carcinoma cells at a concentration of $100 \mu \mathrm{g} / \mathrm{mL}$. Metabolite profiling of Bacillus safensis, Pseudomonas cichorii, and Arthrobacter pascens crude extracts revealed the presence of known antibacterial and/or anticancer agents such as lycorine (1), angustine (2), crinamidine (3), vasicinol (4), and powelline. It can be concluded that the crude bacterial endophyte extracts obtained from $C$. macowanii leaves can biosynthesize bioactive compounds and can be bioprospected for medical application into antibacterial and anticancer agents.
\end{abstract}

\section{Introduction}

The emergence of infectious diseases worldwide due to bacteria and viruses still poses a serious public health concern, claiming the lives of half a million people a year and amounting to $25 \%$ of the total deaths worldwide [1]. Even with the discovery and production of new and improved antibiotics, the resistance of pathogenic microorganisms to drugs has increased enormously [2]. Ventola [3] indicated that the causes of antibiotic resistance include overuse, inappropriate prescribing, and extensive agricultural use. There is, therefore, an imminent need to discover and 
develop new drugs to combat antimicrobial resistance [4]. The World Health Organization (WHO) has declared that antibiotic resistance is a global public health concern, claiming that there are at least 700,000 annual deaths globally $[5,6]$. Novel therapies ought to be discovered to combat antimicrobial resistance [7]. Bacterial infection attributes about $15 \%$ of cancers worldwide and, therefore, is a serious health concern [8].

In South Africa, brain cancer seems to be more prevalent in males $(0.57 \%)$ than females $(0.38 \%)$ [9]. Gliomas are common primary central nervous system (CNS) tumors mostly affecting the brain [10]. Glioblastomas are aggressive cancers with poor prognosis and an average patient survival of 18 months [11]. In South Africa, lung cancer is more common in males with $4.91 \%$ and females with $2.52 \%$ [9]. Lung cancer has been deemed as one of the most prevalent cancers in the developed world and has a very poor survival rate since most patients are diagnosed at a stage when curative treatment is impossible. It is one of the hardest cancers to diagnose [12]. The WHO has ranked cancer as the first leading cause of death globally to people below the age of 70 years, with an estimate of 18.1 million new cancer cases and 9.6 million deaths from cancer in the year 2018 [13]. Kumar et al. [14] described that discovery and development of chemotherapeutic agents are vital in the treatment of cancer, since currently used therapies are ineffective and have side effects, and many important anticancer drugs, such as camptothecin, penochalasin A, and chaetoglobosin $\mathrm{E}$, have been isolated from endophytes. Therefore, further investigations on bacterial endophytes have to be conducted.

Endophytes have been reported from different plant species and plant parts, in various geographical locations and diverse environmental conditions [15]. Endophytes inhabit their host plants; they improve drought tolerance and produce protective compounds which protect host plants from biotic and abiotic factors [16]. Furthermore, Dembitsky [17] reported that endophytes produce bioactive secondary metabolites, such as alkaloids and lactones that display antimicrobial and anticancer properties. These bioactive compounds could be explored further for medical, agricultural, and pharmaceuticals use [18]. Endophytes inhabit unique biological niches growing in uncommon environments, and their isolation and identification are vital for further exploration $[19,20]$.

Crinum macowanii Baker is a medicinal plant native to east, central, and southern Africa [21]. The bulbs, leaves, and roots of C. macowanii possess medicinal properties and have been used traditionally to treat or manage animal and human diseases $[20,21]$. The different plant parts are used for chest pains, diarrhea, tuberculosis, and stimulate milk production in cattle and, thus, are overexploited and overharvested for medicinal purposes [21]. Biological activities of secondary metabolites are attributed to the components working in a mixture of compounds (synergy) as compared to when in isolation [22]; therefore, metabolite fingerprinting of crude endophytes extracts is vital in drug discovery. Morare et al. [24] and Sebola et al. [25] reported on the isolation of bacterial endophytes from the bulbs and the antibacterial activities of their crude extracts, leaving bacterial endophytes isolated from the leaves unexplored. Mixtures of natural extracts are effective in the search for new drugs since they reduce drug-resistant phenotype and hence this study was conducted [26].

The main aim of this study was to isolate and identify bacterial endophytes from Crinum macowanii leaves and to explore the role of endophytic crude extracts as potential antibacterial and anticancer therapeutic agents and further profiling of the secondary metabolite produced by the isolated endophytes as a means to halt the overharvesting of Crinum macowanii leaves.

\section{Materials and Methods}

2.1. Sample Collection. The collection of the leaves was done according to a method described by Sebola et al. [25], where fresh, healthy C. macowanii leaves showing no apparent symptoms of disease or herbivore damage were collected from the Walter Sisulu National Botanical Garden (Roodepoort, Gauteng, South Africa, $\left.26^{\circ} 05^{\prime} 10.4^{\prime \prime} \mathrm{S} 27^{\circ} 50^{\prime} 41.5^{\prime \prime} \mathrm{E}\right)$. After collection, the samples were placed in sterile polyethylene bags and transferred to the laboratory at $4^{\circ} \mathrm{C}$ before being thoroughly washed with sterile distilled water and used within hours of harvesting.

2.2. Isolation of Bacterial Endophytes. Bacterial endophytes were isolated from the leaves of the plant by a method described by Jasim et al. [27] and Sebola et al. [25] with minor modifications. Briefly, the leaves were cut into small pieces of about $10 \mathrm{~cm}$ using a sterile pair of scissors. The cut leaves were treated with 5\% Tween 20 (SigmaAldrich, South Africa) (enough to cover the plant material) and vigorously shaken for 5 minutes. Tween 20 was removed by rinsing several times with sterile distilled water, followed by disinfection with $50 \mathrm{~mL}$ of $70 \%$ ethanol for 1 minute. Traces of the ethanol were removed by rinsing with sterile distilled water 5 times. The sample was then treated with $1 \%$ sodium hypochlorite $(\mathrm{NaClO})$ for 10 minutes and again rinsed five times with sterile distilled water. The last rinse was used as a control, and $100 \mu \mathrm{L}$ of this was plated on Potato Dextrose agar (PDA) (HiMedia, USA) and Nutrient Agar (NA) (Oxoid, USA). The sample was then macerated in sterilized phosphate-buffered saline (PBS). The macerated sample was serially diluted up to $10^{-3}$ dilution, and each dilution was inoculated (using a spread plate method) in triplicate on nutrient agar. The NA plates were incubated at $30^{\circ} \mathrm{C}$ (IncoTherm, Labotec, Johannesburg, South Africa). Growth was monitored periodically for 5 days. The effectiveness of the sterilization was monitored on the wash control plate, with growth indicating poor sterilization. Under such circumstances, the plates for the plant part were discarded and the sterilization was repeated. Distinct colonies were selected and subcultured on nutrient agar to obtain pure isolates. Pure bacterial isolates were preserved in 50\% 
glycerol in a ratio of $500 \mu \mathrm{L}$ glycerol: $500 \mu \mathrm{L}$ overnight broth culture and kept at $-80^{\circ} \mathrm{C}$.

\subsection{Morphological Identification of Endophytic Bacteria}

2.3.1. Gram Staining. To determine the shape and Gram stain reaction, a method described by Sandle [28] was used. Pure colonies were subjected to Gram staining to establish morphological characteristics such as shape and Gram stain reaction. Gram stain slides were observed using a compound bright-field microscope (OLYMPUS CH20BIMF200) with 1000x magnification.

\subsection{Molecular Identification}

2.4.1. Genomic DNA Extraction, Polymerase Chain Reaction, and Sequencing. The 16S rRNA gene of the bacterial endophyte was amplified according to a method described by Kuklinsky-Sobral et al. [28]. DNA extraction was done using a ZR Fungal/Bacterial Kit ${ }^{\mathrm{TM}}$ (Zymo Research, catalog NO R2014) according to the manufacturer's instructions. Polymerase chain reaction (PCR) was done to amplify the $16 \mathrm{~S}$ rRNA gene of each bacterial endophyte with the primers 16S-27F: $5^{\prime}$ AGAGTTTGATCMTGGCTCAG- $3^{\prime}$ and 16S-1492R: $5^{\prime}-$ CGGTTACCTTGTTACGACTT- ${ }^{\prime}$, using DreamTaq ${ }^{\mathrm{Tm}}$ DNA polymerase (Thermo Scientific $\left.{ }^{\mathrm{TM}}\right)$. PCR products were gel extracted (Zymo Research, Zymoclean ${ }^{\mathrm{TM}}$ Gel DNA Recovery Kit) and sequenced in the forward and reverse directions on the ABI PRISM ${ }^{\mathrm{TM}}$ 3500xl Genetic Analyzer. The sequencing was performed at Inqaba Biotechnical Industries (Pty) Ltd., Pretoria, South Africa. The PCR products were cleaned with ExoSAP-it ${ }^{\mathrm{TM}}$ following the manufacturer's recommendations. Purified sequencing products (Zymo Research, ZR-96 DNA Sequencing Clean-up $\mathrm{Kit}^{\mathrm{TM}}$ ) were analyzed using CLC Main Workbench 7, followed by a BLAST search (NCBI).

2.5. Phylogenetic Analysis. The obtained sequences were screened for chimeras using DECIPHER23 and subjected to BLAST analysis using the National Center for Biotechnology Information (NCBI) database against the 16S rDNA sequence database (bacteria and archaea) to identify the closest bacterial species. Bacterial species with $98-100 \%$ similarities were selected for phylogenetic analysis. Alignments of nucleotide sequences were performed using MUSCLE with default options. The positions containing gaps or missing nucleotide data were eliminated. Phylogenetic trees were constructed using a Neighbor-Joining (NJ) method (Saitou and Nei, 1987) based on the Tamura-Nei model [29]. A total of 1000 replications were used for bootstrap testing. All branches with greater than $50 \%$ bootstraps were considered to be significant [31]. All evolutionary analyses were conducted in MEGA 7.0 [31]. The 16S rRNA gene sequences of bacterial isolates identified in the study were deposited in GenBank (https://www.ncbi.nlm.nih.gov/genbank/) with the accession numbers as stated in Table 1 . The assigned names of the bacterial isolates were based on the BLAST homology percentages as well as the phylogenetic results.
2.6. Extraction of Crude Extracts from C. macowanii Leaves. The extraction of secondary metabolites from the leaves was carried out using the method previously described by Yadav and Agarwala [32] and Sebola et al. [25]. C. macowanii leaves were washed, cut into small pieces, and air-dried at room temperature. The dried plant material was blended into a fine powder using a commercial blender. $150 \mathrm{~g}$ of the prepared plant material was mixed with $2 \mathrm{~L}$ of a 50:50 methanol: dichloromethane solution. This was allowed to shake for 3 days on a platform shaker (Amerex Gyromax, Temecula, CA, USA) at $200^{\circ} \mathrm{rcf}$. The solution was filtered through Whatman No. 1 filter paper; the filtrate was evaporated on a rotatory evaporator and allowed to air dry in a desiccator.

2.7. Extraction of Crude Extracts from Bacterial Endophytes. The extraction of crude extracts from each isolated endophytic bacterium was carried out using the method previously described by Sebola et al. [25]. Briefly, LB broth (1 L) was prepared in $2 \mathrm{~L}$ of broth and was measured into a $4 \mathrm{~L}$ Erlenmeyer flask leaving room for aeration and autoclaved at $121^{\circ} \mathrm{C}$ for $15 \mathrm{~min}$. Each $4 \mathrm{~L}$ flask was inoculated with one of the endophytic bacteria as listed in Table 1 , shaken at $200^{\circ} \mathrm{rcf}$, and incubated at $30^{\circ} \mathrm{C}$, an ideal temperature for the growth of the endophytes [33]. After 7 days of cultivation, sterile XAD-7- HP resin (20 g/L) (Sigma, Johannesburg, South Africa, BCBR6696V) was added to the culture for $2 \mathrm{~h}$, shaken at $200 \mathrm{rcf}$. The resin was filtered through cheesecloth and washed three times with $300 \mathrm{~mL}$ of acetone for each wash. The acetone soluble fraction was concentrated using a rotary evaporator, and a dark yellowish viscous extract was obtained, which was transferred into a measuring cylinder. Depending on the volume, ethyl acetate was added in a ratio of $1: 1(\mathrm{v} / \mathrm{v})$. The mixture was vigorously shaken for about $10 \mathrm{~min}$, decanted into a separating funnel, and allowed to separate and each phase is collected in a conical flask. This process was repeated until the dark yellowish viscous liquid obtained after removing the acetone became a very lightyellow liquid. The ethyl acetate fraction was evaporated using a rotary evaporator, and the brown extract obtained was stored in an amber bottle in a cool dry place until the analysis was done. The light-yellow liquid was evaporated, and no reasonable extract or further analysis was done on this substance. The brown crude endophyte extracts were used for antibacterial and anticancer assays and metabolite fingerprinting.

2.8. Antibacterial Analysis of Crinum macowanii Bulbs Crude Extracts and Endophytic Bacterial Crude Secondary Metabolite Extracts. The evaluation of the antimicrobial activity of the crude secondary metabolite extract was performed using the minimum inhibition concentration (MIC) method as previously described by Sebola et al., Sebola et al., and Andrews, [25, 34, 35]. Eleven pathogenic bacterial species, namely, Bacillus cereus (ATCC10876), Bacillus subtilis (ATCC19659), Streptococcus epidermidis (ATCC14990), Staphylococcus aureus (ATCC25923), M. smegmatis (ATCC21293), Mycobacterium marinum (ATCC927), 
TABle 1: Endophytic bacteria isolated from C. macowanii leaves.

\begin{tabular}{lccccc}
\hline Sample code & Assigned bacterial name & GenBank accession number & Similarity (\%) & Gram reaction & $\begin{array}{c}\text { Colony } \\
\text { morphology (pigmentation, } \\
\text { texture, form) }\end{array}$ \\
\hline TES 02B & Raoultella ornithinolytica & MF943227 & 99 & -Rod & Cream white, moist, circular \\
TES 02C & Acinetobacter guillouiae & MF943228 & 100 & -Rod & Cream white, dry, circular \\
TES 05A & Pseudomonas sp. & MF943233 & 99 & -Rods & White, dry, filamentous \\
TES 05B & Pseudomonas palleroniana & MF943234 & 100 & - Rods & Pale yellow, viscid, filamentous \\
TES 06A & Pseudomonas putida & MF943235 & 99 & -Rods & Milky white, moist, circular \\
TES 07A & Bacillus safensis & MF943236 & 100 & +Rod & Milky white, viscoid, circular \\
TES 07B & Bacillus safensis & MF943237 & 100 & +Rod & White, dry, circular \\
TES 10A & Enterobacter asburiae & MF943239 & 99 & -Rod & Pale yellow, moist, filamentous \\
TES 14A & Pseudomonas cichorii & MF943243 & 99 & -Rods & Yellow, moist, circular \\
TES 15A & Arthrobacter pascens & MF943244 & 99 & +Rods & Cream white, viscid, circular \\
\hline
\end{tabular}

Enterobacter aerogenes (ATTC13048), Escherichia coli (ATCC10536), Klebsiella pneumonia (ATCC10031), Proteus vulgaris (ATCC 33420), and Proteus aeruginosa (ATCC10145) were used. The antibiotic Streptomycin was used as the positive control and was prepared by weighing $0.032 \mathrm{mg}$ in $1 \mathrm{~mL}$ of sterile distilled water while $0.1 \%$ DMSO was used as a negative control.

2.8.1. Sample Preparation. The crude leave extract and crude endophytic extracts were weighed separately into empty autoclaved McCartney bottles to ensure sterility. A minimal amount of dimethyl sulfoxide (DMSO) $(0.1 \%)$ was used to dissolve the crude extracts, and Mueller-Hinton ( $\mathrm{MH})$ broth was added to bring the volume of the dissolved crude extract to a concentration of $32 \mathrm{mg} / \mathrm{mL}$ as the stock solution.

2.8.2. Microtiter Plate Assay. Serial dilutions were carried out using the $\mathrm{MH}$ broth from $16 \mathrm{mg} / \mathrm{mL}$ down to $0.031 \mathrm{mg} /$ $\mathrm{mL}$, which was the lowest inhibition observed. The experiment was carried out in five repeats using a 96-well microtiter plate. The outer wells of the plate were filled with sterile distilled water $\left(\mathrm{sdH}_{2} \mathrm{O}\right)$. The inoculum $(100 \mu \mathrm{L})$ was added to each well that did not contain the $\mathrm{sdH}_{2} \mathrm{O}$. The diluted crude extract samples $(100 \mu \mathrm{L})$ were added in five wells horizontally, and the concentrations decreased in a vertical order from $16 \mathrm{mg} / \mathrm{mL}$ down to $0.031 \mathrm{mg} / \mathrm{mL}$. The plates were covered and incubated overnight at $37^{\circ} \mathrm{C}$. After incubation, $10 \mu \mathrm{L}$ of $0.02 \%$ (w/v) Resazurin sodium salt dye solution was added to the wells, and the resulting solution was incubated for another two hours. On reduction, resazurin changes color from blue to pink to clear as oxygen becomes limited within the medium, indicating metabolism and the viability of bacterial cells, as well as no effect of the crude extracts on the bacteria. Any well with a known concentration showing a slight color change was used as MIC. The wells were visually inspected for color changes.

2.9. Anticancer Assays. The evaluation of the anticancer activity of the crude secondary metabolite extract was performed using the MTS (3-(4, 5-dimethylthiazol-2-yl)-5-(3carboxymethoxy-phenyl)-2-(4-sulfophenyl)-2H-tetrazolium) assay as previously described by Sebola et al. [25]. A stock solution of $200 \mu \mathrm{g} / \mathrm{mL}$ of all crude extracts (leave crude extracts and endophytic crude extract) was prepared in $0.1 \%$ DMSO and sonicated. Serial dilutions were done according to [36, 37]. Briefly, dilutions were carried out using growth media from $100 \mu \mathrm{g} / \mathrm{mL}$ to $3.13 \mu \mathrm{g} / \mathrm{mL}$. MTS (3-(4, 5-dimethylthiazol-2-yl)-5-(3-carboxymethoxy-phenyl)-2-(4-sulfophenyl)-2H-tetrazolium) in vitro cancer cytotoxicity assay was carried out to determine a change in cell viability through the use of a color change. The MTS compound (yellow) is metabolized by viable cells to form a dark purple-colored compound, while dead cells turn the color of the MTS compound pink. The samples were run in duplicate across three plates $(n=6)$, and the average values obtained were reported. The U87MG (glioblastoma) cells and A549 (lung carcinoma) cells were grown using normal tissue culture techniques using Dulbecco's Modified Eagle Medium (Merk, Johannesburg, SA) supplemented with $15 \%$ fetal bovine serum (FBS) (Merck, Johannesburg, SA). The cells $\left(1 \times 10^{5}\right.$ cells/ $\mathrm{ml}$ ) were incubated in 96 -well plates at $37^{\circ} \mathrm{C}$ overnight, with the subsequent addition of the crude bulb extracts and crude endophytic extracts, in concentrations of $100 \mu \mathrm{g} / \mathrm{mL}, 50.0 \mu \mathrm{g} /$ $\mathrm{mL}, 25.0 \mu \mathrm{g} / \mathrm{mL}, 12.5 \mu \mathrm{g} / \mathrm{mL}, 6.25 \mu \mathrm{g} / \mathrm{mL}, 3.125 \mu \mathrm{g} / \mathrm{mL}$, and $0 \mu \mathrm{g} / \mathrm{mL}$. The cells were left to incubate for 4 days, whereupon MTS $(5 \mu \mathrm{L})$ (Promega, Madison, WI, USA) was added to the cells. The absorbance values were measured at $490 \mathrm{~nm}$ after $1 \mathrm{hr}, 2 \mathrm{hr}$, and $4 \mathrm{hr}$ incubation periods. Cell viability was then calculated using the formula

$$
\% \text { Cell viability }=\frac{\left(E_{\mathrm{a}}-B_{\mathrm{a}}\right)}{\left(C_{\mathrm{a}}-B_{\mathrm{a}}\right)} \times 100,
$$

where $E_{\mathrm{a}}$ is the absorbance of the extract, $B_{\mathrm{a}}$ is the absorbance of the blank, and $C_{\mathrm{a}}$ is the absorbance of the control [39]. The positive control used for all conducted tests was auranofin, as it is able to inhibit thioredoxin reductase as well as the ubiquitin-proteasome system (UPS) by targeting proteasome-associated deubiquitinase, thus inducing lung cancer cell apoptosis by selenocystine [39-41].

\subsection{LC-QTOF-MS Analysis}

2.10.1. Instrumentation. Secondary metabolites of the crude leave extracts and crude endophytes extracts were identified using an LC-QTOF system with a Dionex UltiMate 3000 
UHPLC (Thermo Scientific, Darmstadt, Germany) coupled to a Compact $^{\mathrm{TM}}$ QTOF (Bruker Daltonics, Bremen, Germany) that uses an electrospray ionization (ESI) interface, following a modified method by Hoffman et al., Changwa et al., Want, Tapfuma et al., and Tapfuma et al. [42-46]. The instrument parameters used in this study are listed in Table 2. Instrument operation control and acquisition was done using HyStar software version 2.1 (Thermo Scientific, Darmstadt, Germany). The analytical run was set at 40 minutes.

The gradient flow used for the mobile phase is listed in Table 3.

2.10.2. Data Processing. Spectral data processing was performed on Bruker Compass DataAnalysis software version 4.3 (Bruker Daltonics, Brem Hub, California, USA). MetFrag web tool version 2.1 software (Git Hub, California, USA) was used to compare fragment patterns of fragmented ions with those from compound databases, namely, PubChem, ChemSpider, and KEGG [48]. Additional databases that were used include METLIN (Scripps Research, California, USA) and KNapSAcK (Kanaya Laboratory, Japan) [49]. Blank containing methanol for plant extracts and NB for bacteria endophytes were also analyzed in the same conditions. Comparison of the two base chromatograms (from the crude extracts and endophyte extracts and the controls) allowed for filtering out impurities from the growth medium $[45,46]$.

\section{Results and Discussion}

3.1. Molecular and Morphological Identification of Bacterial Endophytes from C. macowanii leaves. Endophytes inhabit unique biological niches growing in unusual environments. Their isolation and identification are vital for further exploration $[49,50]$. In this study, a total of 9 bacterial endophytes were isolated and characterized from the leaves of C. macowanii. as seen in Table 1 .

Seven Gram-negative bacteria were observed. Phenotype diversity of the endophyte contributes to the Gram reaction and colony morphology of the endophytes [51] and hence the diverse endosphere, while the growth rate and size of the host plant also have an effect on the diverse endophytic community [52]. The endophytic community of plants is influenced by the age of the host plant, geographic location, and abiotic factors such as temperature $[52,53]$. This would explain the diversity of the bacterial endophytes isolated.

Bacterial genera including Pseudomonas, Bacillus, and Burkholderia have been isolated as endophytes from leaves of medicinal plants [54]. These bacteria genera predominate in medicinal plants, as they assist the host plant in mineral nutrient composition and protection against abiotic and biotic stresses [55]. The BLAST search conducted of the results of the $16 \mathrm{~S}$ rDNA gene sequence revealed that the isolated endophytes belong to bacterial genera, such as Raoultella, Acinetobacter, Pseudomonas, Bacillus, Enterobacter, and Arthrobacter, as seen in Figure 1. This supports our observed results.
Pseudomonas are common bacteria associated with plants and have been isolated from a number of plant species and tissues. They display a positive effect on host plant growth such as reducing drought stress and producing plant hormones such as 1-aminocyclopropane-1-carboxylic acid (ACC) and Indole-3-acetic acid (IAA) and acting as biocontrol agents [26, 49, 56, 57]. Our isolate TES05A showed 94\% similarity with Pseudomonas sp. WB4.4-99. Endophytic isolate TES14A showed $83 \%$ similarity with Pseudomonas cichorii Pc-Gd-1. Endophytic Pseudomonas cichorii has been isolated from potato cultivar [58]. Isolate TES06A displayed a 99\% similarity with Pseudomonas putida PF45. Endophytic Pseudomonas putida have been isolated from mango orchard [59]. Isolate TES05B showed 99\% similarity with Pseudomonas palleroniana IHB B 7234. Endophyte Pseudomonas palleroniana has been isolated from bananas and is reported to fix free nitrogen, solubilize phosphates, and produce siderophores in vitro [60].

TES02C displayed a sequence identity of $100 \%$ to Acinetobacter guillouiae OTU-b62. Different Acinetobacter species have been isolated from potato cultivars [58]. TES15A isolates revealed $100 \%$ to Arthrobacter pascens $\mathrm{H} 19$. Arthrobacter spp. has been isolated from ethnomedicinal plants in Southern India [61]. Bacillus endophytes have been isolated from sunflower, potatoes, and cotton and assist host plants in phosphate solubilization and auxin production [56]. Our endophytic isolates (TES07A and TES07B) displayed $100 \%$ similarity to Bacillus safensis TMV13-3. Bacillus spp. Isolates TES02B had a similarity of $62 \%$ to Raoultella terrigena $m$ 5. Endophytic Raoultella ornithinolytica has been isolated from mountain-cultivated ginseng plants [62]. A 64\% similarity was observed between our isolate TES10A and Enterobacter asburiae E6 - 2. Endophytic Enterobacter asburiae has been isolated from date palm and promotes plant growth [63].

To the best of our knowledge, this is the first report on the isolation of Arthrobacter pascens and Enterobacter asburiae from C. macowanii.

\subsection{Antibacterial Evaluation of Crude Bacteria Endophyte} Extracts from the Leaves. The lowest MIC $(0.0625 \mathrm{mg} / \mathrm{mL})$ was observed from Arthrobacter pascens crude extract and crude extracts against $B$. subtilis, respectively. The crude extracts of most of the endophytes showed MIC values below $1.00 \mathrm{mg} / \mathrm{mL}$. The leave crude extracts displayed noteworthy activity against both Gram-positive and Gram-negative bacteria as seen in Table 4 .

C. macowanii leaves have been used traditionally to cleanse the blood, treat coughs, kidney, and bladder diseases in humans and animals, and also $t$ treat coughs and diarrhea [20]. The results obtained in this study indicate the inhibition of B. subtilis, M. smegmatis, and $P$. vulgaris at $0.500 \mathrm{mg} / \mathrm{mL}$, and S. aureus, E. coli, and K. pneumonia were inhibited at $0.250 \mathrm{mg} / \mathrm{mL}$ and $S$. epidermidis and $P$. aeruginosa at $1.00 \mathrm{mg} / \mathrm{mL}$ and $0.125 \mathrm{mg} / \mathrm{mL}$, and respectively.

These data provide scientific justification for the ethnomedicinal uses of the leaves, as the inhibited bacteria are 
TABle 2: Parameters of the LC-QTOF-MS/MS system.

\begin{tabular}{lc}
\hline Specification & Setting \\
\hline $\begin{array}{l}\text { Column } \\
\text { Injection volume }\end{array}$ & $\begin{array}{r}\text { Raptor ARC-18 column with dimensions of } 2.7 \mu \mathrm{m} \text { (particle size), 2.1 mm (internal diameter), } 100 \mathrm{~mm} \\
\text { (length) and } 90 \AA \text { (pore size) (Restek, Bellefonte, USA }\end{array}$ \\
$\begin{array}{l}\text { Operating } \\
\text { Capillary voltage at }\end{array}$ & $\begin{array}{c}5 \mu \mathrm{L} \\
\text { End plate offset }\end{array}$ \\
$\begin{array}{l}\text { Dry heater nebulizer gas } \\
\text { pressure }\end{array}$ & $-500 \mathrm{~V}$ \\
Scan & $1.8 \mathrm{bar}$ \\
\hline
\end{tabular}

Table 3: Gradient flow profiles of the mobile phase.

\begin{tabular}{lccc}
\hline Time $(\mathrm{min})$ & Flow $(\mathrm{mL} / \mathrm{min})$ & Solvent A $\left(0.1 \%\right.$ formic acid in $\left.\mathrm{H}_{2} \mathrm{O}(\mathrm{v} / \mathrm{v})\right)$ & Solvent B $(0.1 \%$ formic acid in acetonitrile $(\mathrm{v} / \mathrm{v}))$ \\
\hline $0-2$ & 300 & 95 & 5 \\
$2-30$ & 300 & 5 & 95 \\
$30-40$ & 300 & 95 & 5 \\
\hline
\end{tabular}

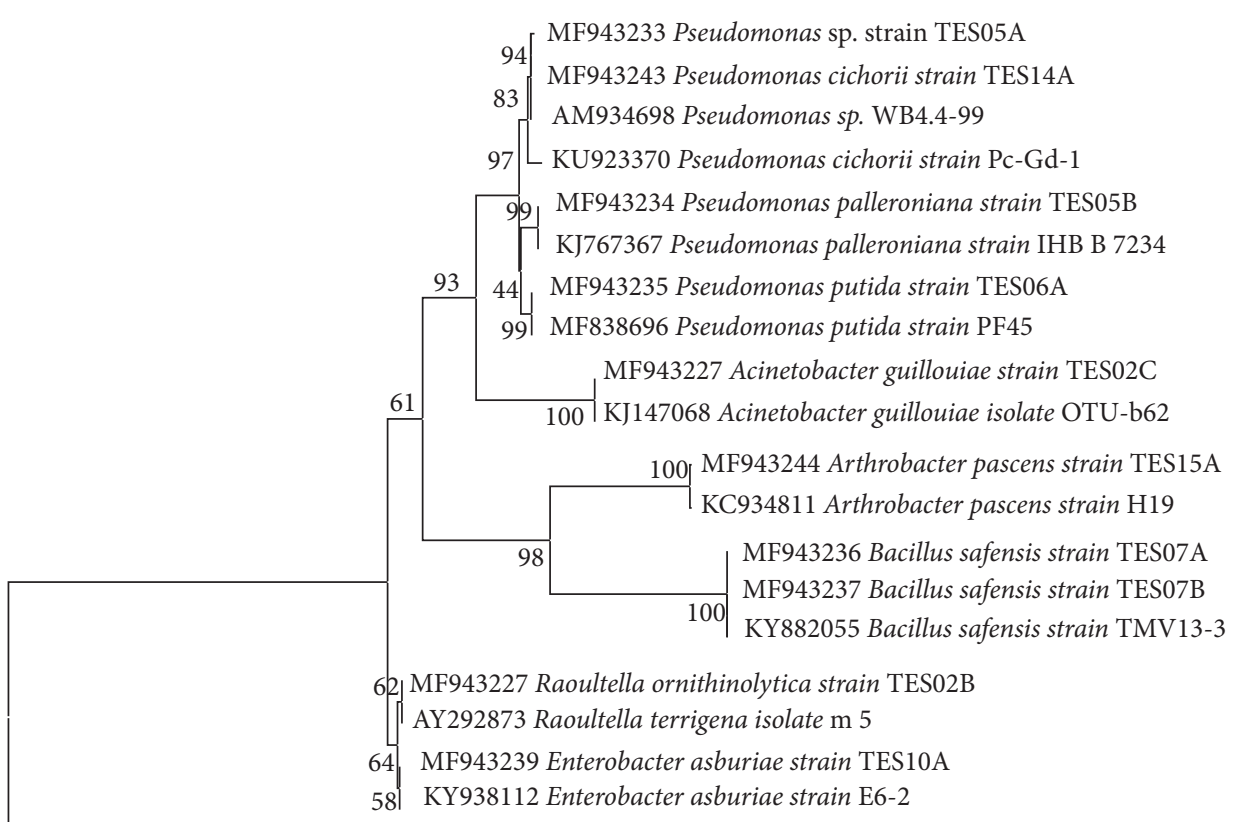

GQ203544 Hypocrea lixii strain SWFC8926

$$
0.10
$$

FIGURE 1: Neighbor-joining phylogenetic tree of $16 \mathrm{~S}$ rRNA gene sequences of endophytes isolated from C. macowanii leaves showing the relationship with other similar species selected from GenBank.

the main causative agents of the ailments the leaves are used to treat. S. aureus, E. coli, and K. pneumoniae were inhibited by a final concentration of $250 \mu \mathrm{g} \cdot \mathrm{mL}^{-1}$ by alkaloids such as crinine, cherylline, crinamidine, 3-O-acetylhamayne, and bulbispermine which have been isolated from C. macowanii leaves [64]. To the best of our knowledge, this study is the first to report on the extraction of crude extract from leaves of C. macowanii and its antibacterial activity.

The cultivation of plants to obtain bioactive compounds has led to drawbacks, such as overharvesting of plants to obtain bioactive compounds, different environmental conditions tend to produce low yields, and total synthesis and semisynthesis are challenging due to complex structures [65]. A number of endophytic microorganisms have produced anticancer, antimicrobial, antidiabetic, insecticidal, and immunosuppressive compounds [66]. Plants growing in a variety of places possibly harbor endophytes with novel natural products $[66,67]$.

Raoultella ornithinolytica crude extract had MIC values ranging from 0.250 to $16 \mathrm{mg} / \mathrm{mL}$, with the most significant 


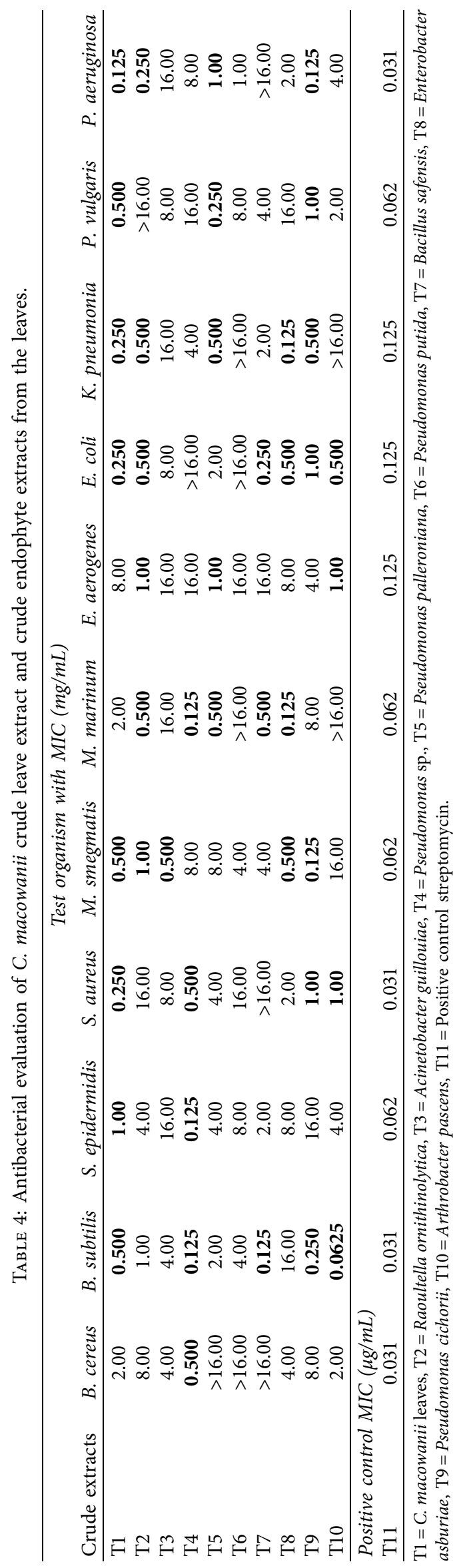


inhibition observed for $K$. pneumonia, $E$. coli, and M. marinum at concentrations of $0.500 \mathrm{mg} / \mathrm{mL}$, and $P$. aeruginosa was inhibited at concentrations of $0.250 \mathrm{mg} /$ $\mathrm{mL}$. Microcin genes have been reported to be present on Raoultella ornithinolytica [62] and microcins are antibacterial peptides produced by Enterobacteria [68]. This could explain the observed results. Acinetobacter guillouiae crude extract showed MIC values of between 0.500 and $16 \mathrm{mg} / \mathrm{mL}$. The crude extract showed activity against $M$. marinum at $0.500 \mathrm{mg} / \mathrm{mL}$.

Bacillus safensis crude extract showed MIC values of between 0.125 and $>16 \mathrm{mg} / \mathrm{mL}$. The crude extract showed activity against $B$. subtilis, $M$. marinum, and $E$. coli at concentrations of $0.125 \mathrm{mg} / \mathrm{mL}, \quad 0.500 \mathrm{mg} / \mathrm{mL}$, and $0.250 \mathrm{mg} / \mathrm{mL}$, respectively. Crude endophytic extracts of Bacillus safensis isolated from Ophioglossum reticulatum L. displayed antibacterial activity against Staphylococcus aureus and Escherichia coli [69]. This is in agreement with the obtained results.

Enterobacter asburiae crude extract showed MIC values of between 0.125 and $16 \mathrm{mg} / \mathrm{mL}$. The crude extract showed activity against $M$. smegmatis and E. coli at concentrations of $0.500 \mathrm{mg} / \mathrm{mL}$ and $M$. marinum and K. pneumonia at concentrations of $0.125 \mathrm{mg} / \mathrm{mL}$. Endophytic crude extracts of Enterobacter asburiae displayed antibacterial activity against K. pneumoniae, E. coli, S. aureus, and B. cereus. Enterobacter strains [70] have been reported to produce antibacterial lipopeptides with a broad activity [71]. This supports the obtained results.

Arthrobacter pascens crude extract showed MIC values of between 0.0625 and $>16 \mathrm{mg} / \mathrm{mL}$. The most active inhibition was against $B$. subtilis at $0.0625 \mathrm{mg} / \mathrm{mL}$. The crude extract showed activity against $S$. aureus and $E$. aerogenes at concentrations of $1.00 \mathrm{mg} / \mathrm{mL}$. Arthrobacilin, an antibacterial compound produced by Arthrobacter spp., showed inhibition against $S$. aureus $[72,73]$. This could explain the antibacterial activity observed.

Pseudomonas sp. crude extract showed MIC values of between 0.0625 and $>16 \mathrm{mg} / \mathrm{mL}$. The most active inhibition was against $M$. marinum at $0.0625 \mathrm{mg} / \mathrm{mL}$. Mupirocin produced by Pseudomonas strains has been reported to possess antibacterial activity [74]. Pseudomonas palleroniana crude extract showed MIC values of between 0.250 and $>16 \mathrm{mg} / \mathrm{mL}$. The most active inhibition was against P. vulgaris at $0.250 \mathrm{mg} / \mathrm{mL}$. The crude extract showed activity against $E$. aerogenes and $P$. aeruginosa at concentrations of $1.00 \mathrm{mg} / \mathrm{mL}$ and $M$. marinum and $K$. pneumonia at concentrations of $0.500 \mathrm{mg} / \mathrm{mL}$. Endophytic crude extracts from Pseudomonas palleroniana were reported to inhibit Escherichia coli and Staphylococcus aureus [50]. Pyoluteorin produced by Pseudomonas palleroniana strains has been reported to contain antibacterial activity [75]. Pseudomonas putida crude extract showed MIC values of between 1.00 and $>16 \mathrm{mg} / \mathrm{mL}$. The most active inhibition was against $P$. aeruginosa at $1.00 \mathrm{mg} / \mathrm{mL}$. Antibiotics pyoluteorin, phenazine-1-carboxamide, and phenazine-1-carboxylic acid were produced by Pseudomonas putida strains [75]. This could explain the antibacterial activity observed. Pseudomonas cichorii crude extract showed MIC values of between
0.125 and $16 \mathrm{mg} / \mathrm{mL}$. The crude extract showed activity against $E$. coli and $P$. vulgaris at concentrations of $1.00 \mathrm{mg} /$ $\mathrm{mL}, M$. smegmatis and $P$. aeruginosa at concentrations of $0.125 \mathrm{mg} / \mathrm{mL}$, B. subtilis at $0.250 \mathrm{mg} / \mathrm{mL}$, and K. pneumonia at $0.500 \mathrm{mg} / \mathrm{mL}$. To the best of our knowledge, this is the first report on the antibacterial activity of crude endophyte extracts from Pseudomonas cichorii.

Cos et al. [76] state that a concentration of $<0.1 \mathrm{mg} / \mathrm{mL}$ for a crude sample is the ideal concentration for anti-infective bioassays whereas $[77,78]$ recommend that crude samples with a concentration of $1.00 \mathrm{mg} / \mathrm{mL}$ and $\leq 100 \mu \mathrm{g} / \mathrm{ml}$ $(0.100 \mathrm{mg} / \mathrm{ml})$ and $\leq 625 \mu \mathrm{g} / \mathrm{ml}$ are considered to be very significant and moderately significant and therefore noteworthy for minimal inhibitory concentration. Stringent endpoints for anti-infective bioassays ought to be set to prevent false results and confusion, taking into consideration the sensitivity of extracts and test microorganisms, extraction methods, and solvents used [66, 67].

It was observed from the results that crude endophyte extract from Pseudomonas sp. and Arthrobacter pascens obtained from C. macowanii leaves had noteworthy antibacterial activity against the pathogenic bacteria used in this study and can be used as antibacterial agents against and M. marinum and B. subtilis infections, respectively.

3.3. Anticancer Evaluation of Crude Bacteria Endophyte Extracts from the Leaves against Resistance Cancer Cell Lines. Secondary metabolites produced by endophytic microorganisms' act as anticancer agents and display significant potential in medical and veterinary treatments [79, 80]. Anticancer agents paclitaxel and podophyllotoxin have been isolated from endophytic microorganisms [81].

3.3.1. Anticancer Evaluation of Crude Bacteria Endophyte Extracts from the Leaves against A549 Lung Carcinoma Cells. Pseudomonas putida and Bacillus safensis crude extracts showed a $47 \%$ and $50 \%$ cell reduction, respectively, against lung carcinoma cells at a concentration of $100 \mu \mathrm{g} / \mathrm{mL}$ as seen in Figure 2.

3.3.2. Anticancer Evaluation of Crude Bacteria Endophyte Extracts from the Leaves against UMG87 Glioblastoma Cells. Acinetobacter guillouiae crude extracts showed a $42 \%$ reduction of UMG87 glioblastoma cells at a concentration of $6.25 \mu \mathrm{g} / \mathrm{mL}$ and Arthrobacter pascens crude extracts displayed cell reduction of $37 \%$ at a concentration of $12.5 \mu \mathrm{g} / \mathrm{ml}$ as seen in Figure 3.

To the best of our knowledge, this is the first report on the anticancer activity of C. macowanii leave crude extracts. No noteworthy activities were observed from the leaves' crude samples against both cell lines used in this study. Bioactive compounds such as lycorine, pretazettine, crinamine, augustine, and galanthamine are noted to appear in C. macowanii leaves and have been reported to possess anticancer activity [82-84].

To the best of our knowledge, this is the first report on the anticancer activity of crude endophytes extracts from 


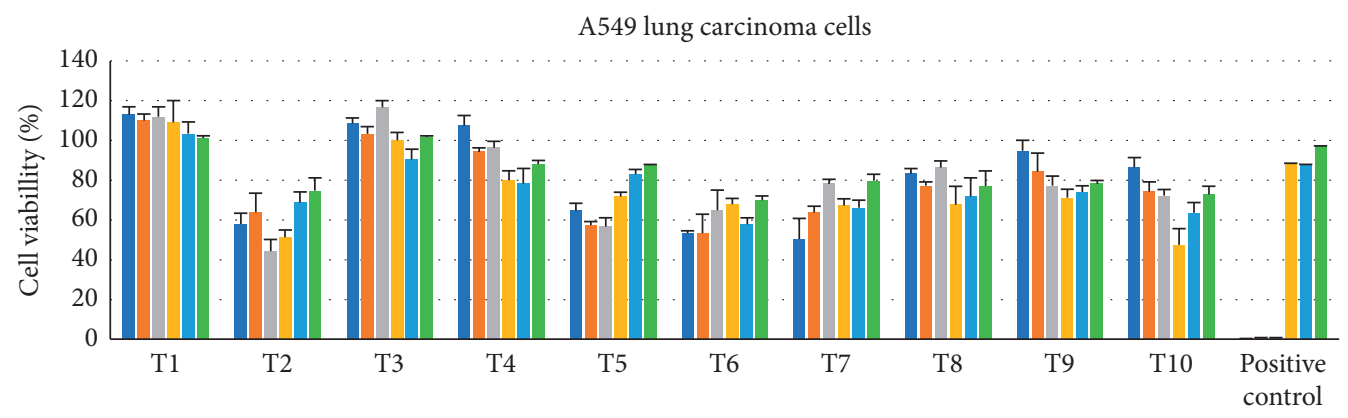

Crude extracts from C. macowanii leaves and endophytes from the leaves

$$
\begin{aligned}
& \text { - } 100 \mu \mathrm{g} / \mathrm{ml} \\
& \text { - } 50.0 \mu \mathrm{g} / \mathrm{ml} \\
& \text { - } 25.0 \mu \mathrm{g} / \mathrm{ml} \\
& \text { - } 12.5 \mu \mathrm{g} / \mathrm{ml} \\
& \text { - } 6.25 \mu \mathrm{g} / \mathrm{ml} \\
& \text { - } 3.13 \mu \mathrm{g} / \mathrm{ml}
\end{aligned}
$$

Figure 2: Cytotoxic activity of endophytic-derived secondary metabolites and crude extracts on A549 lung carcinoma cells tested at different concentrations ranging from 100 to $3.13 \mu \mathrm{g} / \mathrm{mL}$. The positive control used was auranofin. T1 =C. macowanii leaves, T2=Raoultella ornithinolytica, T3=Acinetobacter guillouiae, T4=Pseudomonas sp., T5=Pseudomonas palleroniana, T6=Pseudomonas putida, T7 = Bacillus safensis, T8 = Enterobacter asburiae, $\mathrm{T} 9=$ Pseudomonas cichorii, $\mathrm{T} 10=$ Arthrobacter pascens.

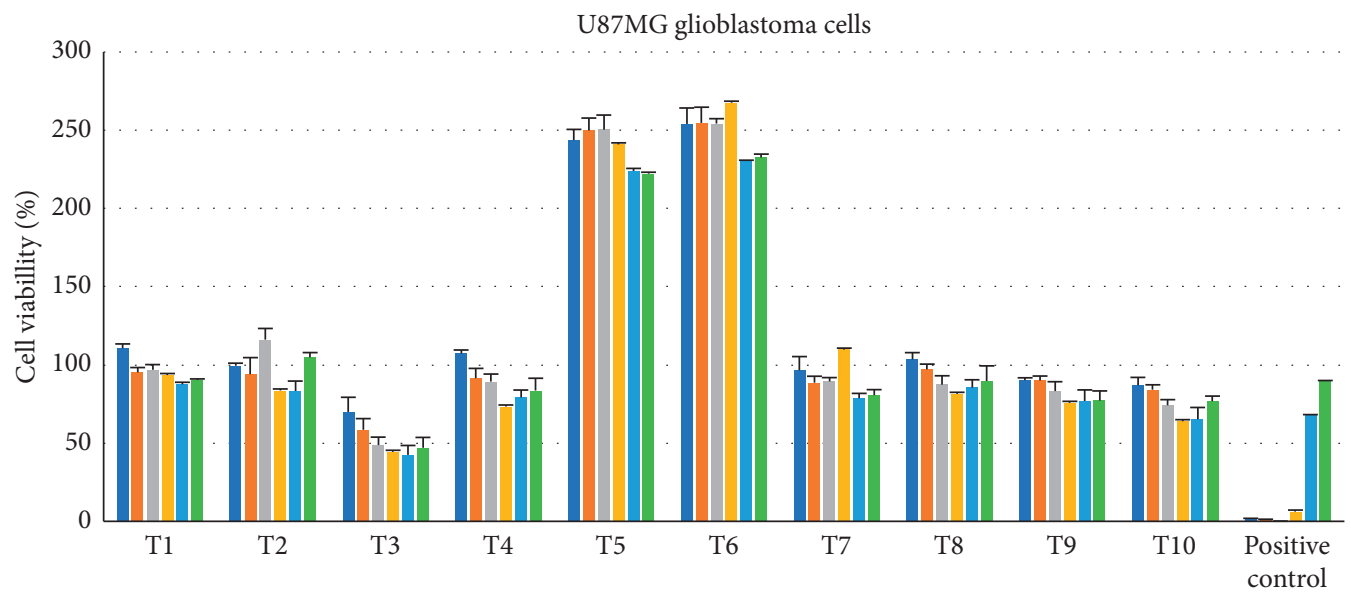

Crude extracts from C. macowanii leaves and endophytes from the leaves

$$
\begin{aligned}
& \text { - } 100 \mu \mathrm{g} / \mathrm{ml} \\
& \text { - } 50.0 \mu \mathrm{g} / \mathrm{ml} \\
& \text { - } 25.0 \mu \mathrm{g} / \mathrm{ml}
\end{aligned}
$$

$$
\begin{array}{r}
12.5 \mu \mathrm{g} / \mathrm{ml} \\
6.25 \mu \mathrm{g} / \mathrm{ml} \\
-3.13 \mu \mathrm{g} / \mathrm{ml}
\end{array}
$$

FIgURE 3: Cytotoxic activity of endophytic-derived secondary metabolites and crude extracts on UMG87 glioblastoma cells tested at different concentrations ranging from 100 to $3.13 \mu \mathrm{g} / \mathrm{mL}$. The positive control used was auranofin. $\mathrm{T} 1=$ C. macowanii leaves, $\mathrm{T} 2=$ Raoultella ornithinolytica, T3=Acinetobacter guillouiae, T4=Pseudomonas sp., T5=Pseudomonas palleroniana, T6=Pseudomonas putida, $\mathrm{T} 7=$ Bacillus safensis, $\mathrm{T} 8=$ Enterobacter asburiae, $\mathrm{T} 9=$ Pseudomonas cichorii, $\mathrm{T} 10=$ Arthrobacter pascens.

Pseudomonas palleroniana, Bacillus safensis, Enterobacter asburiae, Arthrobacter pascens, and Pseudomonas cichorii.

Acinetobacter guillouiae crude endophyte extract was the only tested sample that exhibited anticancer against UMG87 glioblastoma cells, with a $31 \%$ cell reduction at $100 \mu \mathrm{g} / \mathrm{mL}$ and $53 \%$ cell reduction at $3.13 \mu \mathrm{g} / \mathrm{mL}$ posing as a possible anticancer agent against brain cancer.

Bacillus safensis crude extracts displayed noteworthy activity against A549 lung carcinoma cells with 50\% cell reduction at $100 \mu \mathrm{g} / \mathrm{mL}$. Crude extracts of Bacillus safensis isolated from sea sponges had anticancer activity against HepG2 (hepatocellular carcinoma), HCT (colon carcinoma), and MCF 7 (breast carcinoma) [85]. This could explain the observed results, and crude endophyte extracts from Bacillus safensis can be used as an anticancer agent against lung cancer.

Crude endophytic extract of Enterobacter asburiae, Pseudomonas sp., Arthrobacter pascens, and Pseudomonas palleroniana displayed no noteworthy activity against UMG87 glioblastoma cells and A549 lung carcinoma cells. The extracts can be tested on other cancer cell lines to determine their activity. Pseudomonas sp. are known to produce anticancer compounds and have been reported to have activity against a number of human cancer cell lines 
[86, 87]. Pseudomonas sp. and Pseudomonas cichorii displayed no noteworthy activity against UMG87 glioblastoma cells and A549 lung carcinoma cells. Pseudomonas palleroniana crude extracts displayed $36 \%$ cell reduction at $100 \mu \mathrm{g} /$ $\mathrm{mL}$ against A549 lung carcinoma cells.

Crude endophyte extracts from Pseudomonas putida displayed $47 \%$ cell reduction at $100 \mu \mathrm{g} / \mathrm{mL}$ against A549 lung carcinoma cells. $P$. putida TJ151 is able to produce fluorouracil which is a bioactive aromatic compound and it is an anticancer drug [59]. L-methioninase, an enzyme produced by Pseudomonas putida, has shown anticancer activity against leukemia cell lines, liver HepG2, breast MCF-7, lung A549, prostate PC3, and colon HCT116 [88, 89]. Methioninase from $P$. putida and 5-fluorouracil work synergistically to inhibit tumor growth and hence the activity observed [90].

Crude endophyte extracts from Raoultella ornithinolytica displayed $43 \%$ cell reduction at $100 \mu \mathrm{g} / \mathrm{mL}$ against A549 lung carcinoma cells. Protein complex from R. ornithinolytica has shown anticancer activity against HeLa cell line, human endometrioid ovarian cancer line (TOV 112D ATCC CRL-11731), and the human breast adenocarcinoma line (T47D ECACC 85102201) resulting in cytopathic effect and reduction in the cell number [91, 92].

Crude endophyte extracts of Raoultella ornithinolytica, Pseudomonas palleroniana, Pseudomonas putida, and $\mathrm{Ba}$ cillus safensis can be further purified and tested for their anticancer activity against other types of the cancer cell line.

3.4. Liquid Chromatography Quadrupole Time-of-Flight Mass Spectrometry LC-Q-TOF-MS Analysis. The isolation and characterization of bioactive secondary metabolites help in distinguishing between new and already known bioactive secondary metabolites which help in the development and discovery of new drug leads [93]. Lycorine and powelline were some of the identified secondary metabolites present in the crude extract of C. macowanii leaves, Bacillus safensis, Pseudomonas cichorii, and Arthrobacter pascens. These are indicated in Table 5.

Not much work has been done to the leaves, and to the best of our knowledge, this is the first report of the identification of secondary metabolites from leaves of C. macowanii and their endophytes using LC-Q-TOF-MS. Endophytes are able to produce similar secondary metabolites as the host plants by exchanging fragments of their genomic DNA with the host plant [103, 104]. These secondary metabolites perform distinct functions such as antibacterial and anticancer activity as performed in this study [105]. Melicopicine is an acridone alkaloid isolated from leaves of Teclea and Zanthoxylum species [94]. An acridone alkaloid melicopicine has been isolated from Melicope fareana [106] and has anthelmintic and antibacterial activities [107]. This would explain the noteworthy antibacterial activity of the crude leave extract observed in this study.

Lycorine is an alkaloid previously isolated from C. macowanii [108]. Leaves of C. macowanii contain more lycorine as compared to the bulbs and other plant parts such as roots and flowers [109]. Crude endophyte extras of $\mathrm{Ba}$ cillus safensis, Pseudomonas cichorii, and Arthrobacter pascens displayed the presence of lycorine, and this is not surprising as endophytes can metabolize secondary metabolites from the host plant [104]. Lycorine has been reported to possess antibacterial activity and cytotoxic and antitumor activities [95]. This would explain the observed antibacterial and/or anticancer activity of the crude endophyte extracts.

Angustine is an alkaloid previously isolated from plants of the Rubiaceae and Loganiaceae family [110]. To the best of our knowledge, angustine is being identified for the first time in C. macowanii leaves extracts and its isolated endophytes.

Aulicine and 3-O-methyl-epimacowine are crinine-type alkaloids and have been isolated from Hippeastrum aulicum Herb. and Hippeastrum calyptratum Herb. [110, 111]. Evidente and Kornienko [97] reported on the anticancer properties of these crinine-type alkaloids. This would justify the anti-lung cancer activity of crude Bacillus safensis endophyte extracts. Different cancer cell lines can be used to determine the anticancer activity of crude Pseudomonas cichorii endophyte extracts.

Crinine-type alkaloid crinamidine has been isolated from different plants of the Amaryllidaceae family [113] and also from the bulbs, flowering stalks, leaves, and roots of Crinum macowanii [21]. Crinamidine is found in whole plant parts of the Crinum species [114]. Powelline is an alkaloid reported to occur in C. macowanii [115] and Ndhlala et al. [115] reported its occurrence from the bulbs. Both these crinine-type alkaloids have been reported to possess antibacterial, antitumor, and anticancer activity [20,98, 100]. This is not alarming as endophytes can metabolize secondary compounds from the host [105] and display a number of biological activities as the host plant.

Vasicinol is a quinazoline alkaloid from Adhatoda zeylanica Medic. [117]. Crude endophyte extracts of Bacillus safensis, Pseudomonas cichorii, and Arthrobacter pascens displayed the presence of this alkaloid; this is not surprising as some quinazoline alkaloids are produced by microbes [118]. Vasicinol can be tested on other resistant pathogenic bacteria to combat antimicrobial resistance, as its antibacterial activity has been reported by Jain et al. [99].

Brefeldin A is a fungal metabolite produced by species of the Ascomycetes [119], and to the best of our knowledge, it is being reported for the first time in bacterial endophytes. Brefeldin A has been reported to possess anticancer activity [101]; different cancer cell lines can be used to determine its anticancer activity with different cell lines.

From the results obtained, varying retention times were observed between the leaves and bacterial endophytes samples, even though the same chromatography conditions were used. Factors such as the affinity of the compounds to the extraction solvents used [120], the change in polarity of the sample being analyzed, and fragments that make up the secondary metabolites detected [121], and the formation of secondary metabolites complexes with extraction solvents used to influence the different retention times observed, as they create a sample matrix [122]. 
TABLE 5: LC-Q-TOF-MS analysis of crude extracts of C. macowanii leaves and their bacterial endophytes.

\begin{tabular}{|c|c|c|c|c|c|}
\hline Compound name & Rt (min/sec) & $m / z$ & $\begin{array}{l}\text { Molecular } \\
\text { formula }\end{array}$ & Reported biological activity & Sample \\
\hline Melicopicine & 5.64 & 330.1351 & $\mathrm{C}_{18} \mathrm{H}_{19} \mathrm{~N}_{1} \mathrm{O}_{5}$ & Antiplasmodial activity [94] & $\mathrm{T} 1$ \\
\hline Lycorine & $\begin{array}{c}1.92 ; 13.76 ; 36.75 \\
7.23\end{array}$ & 288.1236 & $\mathrm{C}_{16} \mathrm{H}_{17} \mathrm{~N}_{1} \mathrm{O}_{4}$ & $\begin{array}{c}\text { Antibacterial cytotoxic and antitumor } \\
\text { activities [95] }\end{array}$ & $\begin{array}{c}\text { T1, T7, T9, } \\
\text { T10 }\end{array}$ \\
\hline Angustine & $\begin{array}{c}10.35 ; 19.23 ; 25.98 ; \\
11.07\end{array}$ & 314.1388 & $\mathrm{C}_{20} \mathrm{H}_{15} \mathrm{~N}_{3} \mathrm{O}_{1}$ & Antiproliferative activity [96] & $\begin{array}{l}\text { T1, T7, T9, } \\
\text { T10 }\end{array}$ \\
\hline $\begin{array}{l}\text { 3-O-methyl } \\
\text { epimacowine }\end{array}$ & 5.63 & 288.1586 & $\mathrm{C}_{17} \mathrm{H}_{21} \mathrm{NO}_{3}$ & Anticancer [97] & $\mathrm{T} 7$ \\
\hline Crinamidine & $\begin{array}{c}17.57 ; 15.50 ; 15.44 \\
6.32\end{array}$ & 318.1348 & $\mathrm{C}_{17} \mathrm{H}_{19} \mathrm{~N}_{1} \mathrm{O}_{5}$ & Antibacterial [21] anticancer activity [98] & $\begin{array}{l}\text { T1, T7, T9, } \\
\text { T10 }\end{array}$ \\
\hline Vasicinol & $\begin{array}{c}4.18 ; 21.69 ; 21.51 \\
8.91\end{array}$ & 205.0977 & $\mathrm{C}_{11} \mathrm{H}_{12} \mathrm{~N}_{2} \mathrm{O}_{2}$ & Antibacterial activity [99] & $\begin{array}{l}\text { T1, T7, T9, } \\
\text { T10 }\end{array}$ \\
\hline Aulicine & 1.99 & 320.1870 & $\mathrm{C}_{18} \mathrm{H}_{25} \mathrm{NO}_{4}$ & Anticancer activity [97] & T9 \\
\hline Powelline & $\begin{array}{c}19.14,14.05,17.98 \\
7.43\end{array}$ & 302.1389 & $\mathrm{C}_{17} \mathrm{H}_{19} \mathrm{~N}_{1} \mathrm{O}_{4}$ & Antitumor [100] antibacterial [21] & $\begin{array}{l}\text { T1, T7, T9, } \\
\text { T10 }\end{array}$ \\
\hline Brefeldin A & 11.52 & 281.1702 & $\mathrm{C}_{16} \mathrm{H}_{24} \mathrm{O}_{4}$ & Anticancer [101] and antifungal [102] & $\mathrm{T} 10$ \\
\hline
\end{tabular}

Note: $\mathrm{T} 1=$ C. macowanii leaves, $\mathrm{T} 7=$ Bacillus safensis, $\mathrm{T} 9=$ Pseudomonas cichorii, $\mathrm{T} 10=$ Arthrobacter pascens.

The identified alkaloids lycorine, crinamidine, and powelline are true alkaloids of the Amaryllidaceae family [120, 124], and this supports the obtained results as Crinum macowanii belongs to this plant family. The availability of these alkaloids leads to overuse and overharvesting of $C$. macowanii to obtain these bioactive compounds $[65,125]$. The bioprospecting of endophyte isolated metabolites could help save the environment since endophytes have been reported to contain similar bioactive compounds as the host plant $[66,126]$ and in some doing medicinal plants are being conserved and revenue is generated by the bioprospecting of metabolites from endophytes [127].

\section{Conclusions}

The study revealed the presence and cohabitating of endophytic bacteria from leaves of C. macowanii, and this has informed us of the microbial community of $C$. macowanii. Crude endophyte extracts displayed notable inhibitory activities against both Gram-positive and Gram-negative bacterial species. Crude extracts endophytes (Pseudomonas putida and Bacillus safensis) exhibited promising anticancer activity against lung cancer. The identified secondary metabolites from the endophytes have reported biological activities, and this data raises the possibility that the overharvesting of C. macowanii for its medicinal properties will be halted. This is a promising lead for drug discovery and bioprospecting. Further extraction of secondary metabolites from endophytes is still needed.

\section{Data Availability}

All the data are provided in full in the results section of this paper apart from the DNA sequences of the bacterial endophytes available at https://www.ncbi.nlm.nih.gov/ genbank, and accession numbers for each endophyte can be found in Table 1 of the manuscript.

\section{Conflicts of Interest}

The authors declare that they have no conflicts of interest.

\section{Acknowledgments}

Tendani Edith Sebola was awarded a scholarship from the CSIR DST-Interbursary Support (IBS) bursary and University of Johannesburg Merit Bursary for postgraduate students. The authors would like to thank Walter Sisulu Botanical Garden for sampling and identification of the plant material and the mass spec team Mr. Eric Morifi, Mr. Thapelo Mbele, and Ms. Refilwe Moepya at the University of the Witwatersrand for assisting with the mass spectrometry experiments. The National Research Foundation (NRF) of South Africa under Grant no. TTK150713125714 funded the collection, analysis, and interpretation for the isolation and identification of bacterial endophytes. The National Research Foundation (NRF) of South Africa under Grant no. 114384 funded the analysis and interpretation of the antibacterial studies. The Department of Science and Technology through the Artificial Wetland Research (AWARE) project funded the analysis and interpretation of the anticancer studies.

\section{References}

[1] N. I. Nii-Trebi, "Emerging and neglected infectious diseases: insights, advances, and challenges," BioMed Research International, vol. 2017, Article ID 5245021, 15 pages, 2017.

[2] J. Davies and D. Davies, "Origins and evolution of antibiotic resistance," Microbiology and Molecular Biology Reviews, vol. 74, no. 3, pp. 417-433, 2010.

[3] C. L. Ventola, "The antibiotic resistance crisis: part 1: causes and threats," Pharmacy and Therapeutics, vol. 40, no. 4, pp. 277-283, 2015.

[4] S. Rajbhandary, Healing Traditions of the Northwestern Himalayas, Springer, Berlin, Germany, 2014.

[5] B. Aslam, W. Wang, M. I. Arshad et al., "Antibiotic resistance: a rundown of a global crisis," Infection and Drug Resistance, vol. 11, pp. 1645-1658, 2018.

[6] D. E. Bloom, S. Black, D. Salisbury, and R. Rappuoli, "Antimicrobial resistance and the role of vaccines," Proceedings of the National Academy of Sciences, vol. 115, no. 51, pp. 12868-12871, 2018. 
[7] J. Ali, Q. A. Rafiq, and E. Ratcliffe, "Antimicrobial resistance mechanisms and potential synthetic treatments," Future Science OA, vol. 4, no. 4, Article ID FSO290, 2018.

[8] D. Mager, "Bacteria and cancer: cause, coincidence or cure? A review," Journal of Translational Medicine, vol. 4, no. 1, pp. 1-18, 2006.

[9] National Cancer Registry South Africa, National Cancer Registry SA Statistics, National Cancer Registry South Africa, Johannesburg, South Africa, 2013.

[10] M. Paolillo, C. Boselli, and S. Sergio, "Glioblastoma under siege: an overview of current therapeutic strategies," Brain Sciences, vol. 8, no. 15, pp. 1-13, 2018.

[11] E. Denicolaï, N. Baeza-Kallee, A. Tchoghandjian et al., "Proscillaridin A is cytotoxic for glioblastoma cell lines and controls tumor xenograft growth in vivo," Oncotarget, vol. 5, no. 21, pp. 10934-10948, 2014.

[12] R. D. Neal, I. J. Robbé, M. Lewis, I. Williamson, and J. Hanson, "The complexity and difficulty of diagnosing lung cancer: findings from a national primary-care study in Wales," Primary Health Care Research \& Development, vol. 16, no. 5, pp. 436-449, 2015.

[13] F. Bray, J. Ferlay, I. Soerjomataram, R. L. Siegel, L. A. Torre, and A. Jemal, "Global cancer statistics 2018: GLOBOCAN estimates of incidence and mortality worldwide for 36 cancers in 185 countries," CA: A Cancer Journal for Clinicians, vol. 68, no. 6, pp. 394-424, 2018.

[14] M. L. V. Kumar, B. Thippeswamy, I. J. Kuppust, and J. H. Virupaksha, "Evaluation of analgesic activities of bacillus," International Journal of Chemical Sciences, vol. 12, no. 1, pp. 272-280, 2014.

[15] J. Arora and K. G. Ramawat, "An introduction to endophytes," Sustainable Development and Biodiversity, Springer, vol. 15, pp. 1-23, Cham, Switzerland, 2017.

[16] J. M. Egan, A. Kaur, H. A. Raja, J. J. Kellogg, N. H. Oberlies, and N. B. Cech, "Antimicrobial fungal endophytes from the botanical medicine goldenseal (Hydrastis canadensis)," Phytochemistry Letters, vol. 17, pp. 219-225, 2016.

[17] V. M. Dembitsky, "Naturally occurring bioactive cyclobutane-containing (CBC) alkaloids in fungi, fungal endophytes, and plants," Phytomedicine, vol. 21, no. 12, pp. 1559-1581, 2014.

[18] P. K. Pandey, S. Singh, R. N. S. Yadav, A. K. Singh, and M. C. K. Singh, "Fungal endophytes: promising tools for pharmaceutical science," International Journal of Pharmaceutical Sciences Review and Research, vol. 25, no. 2, pp. 128-138, 2014.

[19] S. R. Joshi and F. M. W. Nongkhlaw, "L-asparaginase and antioxidant activity of endophytic bacteria associated with ethnomedicinal plants," Indian Journal of Biotechnology, vol. 14, pp. 59-64, 2015.

[20] K. Eljounaidi, S. K. Lee, and H. Bae, "Bacterial endophytes as potential biocontrol agents of vascular wilt diseases-review and future prospects," Biological Control, vol. 103, pp. 62-68, 2016.

[21] A. Maroyi, "A review of ethnoboatany, therapeutic value, phytochemistry and pharmacology of Crinum macowanii Baker: a highly traded bulbous plant in Southern Africa," Journal of Ethnopharmacology, vol. 194, pp. 595-608, 2016.

[22] J. M. Watt and M. G. Breyer-Brandwijk, Medicinal and Poisonous Plants, E \& S.Livingstone Ltd, vol. 1964855, London, UK, 2nd. edition, 1962.

[23] M. D. Olufunke, "Developments in phytochemistry," in Drug Discovery Research in Pharmacognosy, P. O. Vallisuta, Ed., pp. 12-23, InTech Open, London, UK, 2012.
[24] R. F. Morare, E. Ubomba-Jaswa, and M. H. Serepa-Dlamini, "Isolation and identification of bacterial endophytes from Crinum macowanii Baker," African Journal of Biotechnology, vol. 17, no. 33, pp. 1040-1047, 2018.

[25] T. E. Sebola, N. C. U. Okereafor, K. I. Tapfuma, L. Mekuto, E. Green, and V. Mavumengwana, "Evaluating antibacterial and anticancer activity of crude extracts of bacterial endophytes from Crinum macowanii Baker bulbs," MicrobiologyOpen, vol. 8, no. 12, pp. 1-10, Article ID e914, 2019.

[26] M. Herranz-López, M. Losada-Echeberría, and E. BarrajónCatalán, "The multitarget activity of natural extracts on cancer : synergy and xenohormesis," Medicines, vol. 6, no. 6, pp. 1-10, 2019.

[27] B. Jasim, A. A. Joseph, C. J. John, J. Mathew, and E. K. Radhakrishnan, "Isolation and characterization of plant growth promoting endophytic bacteria from the rhizome of Zingiber officinale," 3 Biotech, vol. 4, no. 2, pp. 197-204, 2014.

[28] T. Sandle, "Gram's stain: history and explanation of the fundamental technique of determinative bacteriology," IST Science and Technology, vol. 54, pp. 3-4, 2004.

[29] J. Kuklinsky-Sobral, W. L. Araújo, R. Mendes, A. A. Pizzirani-Kleiner, and J. L. Azevedo, "Isolation and characterization of endophytic bacteria from soybean (Glycine max) grown in soil treated with glyphosate herbicide," Plant and Soil, vol. 273, no. 1-2, pp. 91-99, 2005.

[30] K. Tamura, G. Stecher, D. Peterson, A. Filipski, and S. Kumar, "MEGA6: molecular evolutionary genetics analysis version 6.0," Molecular Biology and Evolution, vol. 30, no. 12, pp. 2725-2729, 2013.

[31] D. E. Soltis and P. S. Soltis, "Applying the bootstrap in phylogeny reconstruction," Statistical Science, vol. 18, no. 2, pp. 256-267, 2003.

[32] S. Kumar, G. Stecher, and K. Tamura, "MEGA7: molecular evolutionary genetics analysis version 7.0 for bigger datasets," Molecular Biology and Evolution, vol. 33, no. 7, pp. 1870-1874, 2016.

[33] R. N. S. Yadav and M. Agarwala, "Phytochemical analysis of some medicinal plants," The Journal of Phytological Research, vol. 3, no. 12, pp. 10-14, 2011.

[34] S. Sardul Singh, K. Suneel, and R. P. Aharwal, "Isolation and identification of endophytic fungi from Ricinus communis Linn. and their antibacterial activity," International Journal of Research in Pharmacy and Chemistry, vol. 4, no. 3, pp. 611-618, 2014.

[35] J. M. Andrews, "Determination of minimum inhibitory concentrations," Journal of Antimicrobial Chemotherapy, vol. 1, no. 48, pp. 5-16, 2001.

[36] T. E. Sebola, D. T. Ndinteh, N. Niemann, and V. Mavumengwana, "Metal analysis, phytochemical and antibacterial investigation of Crinum macowanii Bulb," in Proceedings of the International Conference on Advances in Science, Engineering, Technology and Natural Resources, Parys, South Africa, November 2016.

[37] J. McCauley, A. Zivanovic, and D. Skropeta, "Bioassays for anticancer activities," Methods in Molecular Biology, vol. 1055, pp. 191-205, 2013.

[38] F. T. Artun, A. Karagoz, G. Ozcan et al., "In vitro anticancer and cytotoxic activities of some plant extracts on HeLa and Vero cell lines," Journal of the Balkan Union of Oncology, vol. 21, no. 3, pp. 720-725, 2016.

[39] D. Handayani, H. Rivai, R. Mulyana, N. Suharti, R. Rasyid, and T. Hertiani, "Antimicrobial and cytotoxic activities of endophytic fungi isolated from antimicrobial and cytotoxic activities of endophytic fungi isolated from mangrove plant 
Sonneratia alba Sm," Journal of Applied Pharmaceutical Science, vol. 8, no. 2, pp. 49-53, 2018.

[40] C. Fan, W. Zheng, X. Fu, X. Li, Y.-S. Wong, and T. Chen, "Enhancement of auranofin-induced lung cancer cell apoptosis by selenocystine, a natural inhibitor of TrxR1 in vitro and in vivo," Cell Death \& Disease, vol. 5, no. 4, 2014.

[41] C. Roder and M. J. Thomson, "Auranofin: repurposing an old drug for a golden new age," Drugs in R\&D, vol. 15, pp. 13-20, 2015.

[42] N. P. Coussens, J. C. Braisted, T. Peryea, G. S. Sittampalam, A. Simeonov, and M. D. Hall, "Small-molecule screens: a gateway to cancer therapeutic agents with case studies of food and drug administration-approved drugs," Pharmacological Reviews, vol. 69, no. 4, pp. 479-496, 2017.

[43] T. Hoffmann, D. Krug, S. Hüttel, and R. Müller, "Improving natural products identification through targeted LC-MS/MS in an untargeted secondary metabolomics workflow," Analytical Chemistry, vol. 86, no. 21, pp. 10780-10788, 2014.

[44] R. Changwa, W. Abia, T. Msagati, H. Nyoni, K. Ndleve, and P. Njobeh, "Multi-mycotoxin occurrence in dairy cattle feeds from the Gauteng province of South Africa: a pilot study using UHPLC-QTOF-MS/MS," Toxins, vol. 10, no. 7, pp. 294-321, 2018.

[45] E. J. Want, "LC-MS untargeted analysis," in Metabolic Profiling Methods and Protocols, G. A. Theodoridis, H. G. Gika, and I. D. Wilson, Eds., pp. 99-116, Humana Press, New York, NY, USA, 2018.

[46] K. I. Tapfuma, N. Uche-Okereafor, T. E. Sebola et al., "Cytotoxic activity of crude extracts from Datura stramonium's fungal endophytes against A549 lung carcinoma and UMG87 glioblastoma cell lines and LC-QTOF-MS/MS based metabolite profiling," BMC Complementary and Alternative Medicine, vol. 19, no. 1, pp. 1-12, 2019.

[47] K. I. Tapfuma, L. Mekuto, M. M. Makatini, and V. Mavumengwana, "The LC-QTOF-MS/MS analysis data of detected metabolites from the crude extract of Datura stramonium leaves," Data in Brief, vol. 25, Article ID 104094, 2019.

[48] I. Blaženovi, T. Kind, J. Ji, and O. Fiehn, "Software tools and approaches for compound identification of LC-MS/MS data in metabolomics," Metabolites, vol. 8, no. 31, pp. 1-23, 2018.

[49] Z.-J. Zhu, A. W. Schultz, J. Wang et al., "Liquid chromatography quadrupole time-of-flight mass spectrometry characterization of metabolites guided by the METLIN database," Nature Protocols, vol. 8, no. 3, pp. 451-460, 2013.

[50] F. M. Nongkhlaw and S. R. Joshi, "Investigation on the bioactivity of culturable endophytic and epiphytic bacteria associated with ethnomedicinal plants," The Journal of Infection in Developing Countries, vol. 9, no. 9, pp. 954-961, 2015.

[51] B. R. Albrectsen, A. B. Siddique, V. H. G. Decker, M. Unterseher, and K. M. Robinson, "Both plant genotype and herbivory shape aspen endophyte communities," Oecologia, vol. 187, no. 2, pp. 535-545, 2018.

[52] J. Martín-garcía, E. Espiga, V. Pando, and J. J. Diez, "Factors influencing endophytic communities in poplar plantations," Silva Fennica, vol. 45, no. 2, pp. 169-180, 2011.

[53] M. Jia, L. Chen, H.-L. Xin et al., "A friendly relationship between endophytic fungi and medicinal plants: a systematic review," Frontiers in Microbiology, vol. 7, pp. 1-14, Article ID 906, 2016.

[54] Z. Erjaee, S. S. Shekarforoush, and S. Hosseinzadeh, "Identification of endophytic bacteria in medicinal plants and their antifungal activities against food spoilage fungi,"
Journal of Food Science and Technology, vol. 56, no. 12, pp. 5262-5270, 2019.

[55] A. L. Khan, S. A. Gilani, M. Waqas et al., "Endophytes from medicinal plants and their potential for producing indole acetic acid, improving seed germination and mitigating oxidative stress," Journal of Zhejiang University-Science B, vol. 18, no. 2, pp. 125-137, 2017.

[56] S. A. Rhoden, A. Garcia, M. C. Santos e Silva, J. L. Azevedo, and J. A. Pamphile, "Phylogenetic analysis of endophytic bacterial isolates from leaves of the medicinal plant Trichilia elegans A. Juss. (Meliaceae)," Genetics and Molecular Research, vol. 14, no. 1, pp. 1515-1525, 2015.

[57] I. Tamošiune, G. Stanien, P. Haimi, V. Stanys, R. Rugienius, and D. Baniulis, "Endophytic Bacillus and Pseudomonas spp. modulate apple shoot growth, cellular redox balance, and protein expression under in vitro conditions," Frontiers in Plant Science, vol. 9, pp. 1-14, Article ID 889, 2018.

[58] T. Ramírez-Bahena, M.-H. Carmen, and A. Peix, "Bacterial endophytes inhabiting potato plants (Solanum tuberosum L.)," in Agricultural Research Updates, P. Gorawala and S. Mandhatri, Eds., vol. 7, pp. 3-31, Nova Science Publishers, New York, NY, USA, 2014.

[59] H. Asif, D. J. Studholme, A. Khan, M. Aurongzeb, I. A. Khan, and M. K. Azim, "Comparative genomics of an endophytic Pseudomonas putida isolated from mango orchard," Genetics and Molecular Biology, vol. 39, no. 3, pp. 465-473, 2016.

[60] C. N. Ngamau, V. N. Matiru, A. Tani, and C. W. Muthuri, "Isolation and identification of endophytic bacteria of bananas (Musa spp.) in Kenya and their potential as biofertilizers for sustainable banana production," African Journal of Microbiology Research, vol. 6, pp. 6414-6422, 2012.

[61] M. S. Nalini and H. S. Prakash, "Diversity and bioprospecting of actinomycete endophytes from the medicinal plants," Letters in Applied Microbiology, vol. 64, no. 4, pp. 261-270, 2017.

[62] G. Shanmugam, A. Dubey, L. N. Ponpandian, and S. O. Rim, "Genomic insights into nematicidal activity of a bacterial endophyte, Raoultella ornithinolytica MG against pine wilt nematode," The Plant Pathology Journal, vol. 34, no. 3, pp. 250-255, 2018.

[63] M. W. Yaish, "Draft genome sequence of endophytic bacterium Enterobacter asburiae PDA134, isolated from date palm (Phoenix dactylifera L.) roots," Genome Announcements, vol. 4, no. 4, pp. 1-2, 2016.

[64] E. E. Elgorashi, S. Zschocke, J. Van Staden, and J. N. Eloff, "The anti-inflammatory and antibacterial activities of amaryllidaceae alkaloids," South African Journal of Botany, vol. 69, no. 3, pp. 448-449, 2003.

[65] A. Venugopalan and S. Srivastava, "Endophytes as in vitro production platforms of high value plant secondary metabolites," Biotechnology Advances, vol. 33, no. 6, pp. 873-887, 2015.

[66] M. A. Abdalla and L. J. Mcgaw, "Bioprospecting of South African plants as a unique resource for bioactive endophytic microbes," Frontiers in Pharmacology, vol. 9, no. 456, pp. 1-18, 2018.

[67] S. Baker and S. Satish, "Endophytes: natural warehouse of bioactive compounds endophytes: natural warehouse of bioactive compounds," Drug Invention Today, vol. 4, no. 11, pp. 548-553, 2012.

[68] J. F. Garcia-Bustos, N. Pezzi, and E. Mendez, "Structure and mode of action of microcin 7, an antibacterial peptide produced by Escherichia coli," Antimicrobial Agents and Chemotherapy, vol. 27, no. 5, pp. 791-797, 1985. 
[69] A. Mukherjee, R. Das, A. Pal, and A. Paul, "Antibacterial activity of endophytic Bacillus safensis isolated from Ophioglossum reticulatum L." Microbiology Research Journal International, vol. 18, no. 5, pp. 1-12, 2017.

[70] A. M. Akinsanya, S. A. Ting, and O. Sanusi, "Extraction methods and TLC-bioautography for evaluation of antimicrobial activities of endophytic bacteria from medicinal plants," LASU Journal of Medical Sciences, vol. 2, no. 1, pp. 1-7, 2017.

[71] S. M. Mandal, S. Sharma, A. K. Pinnaka, A. Kumari, and S. Korpole, "Isolation and characterization of diverse antimicrobial lipopeptides produced by Citrobacter and Enterobacter," BMC Microbiology, vol. 13, pp. 1-9, Article ID 152, 2013.

[72] M. Wietz, M. Månsson, J. S. Bowman, N. Blom, Y. Ng, and L. Gram, "Wide distribution of closely related, antibioticproducing arthrobacter strains throughout the arctic ocean," Applied and Environmental Microbiology, vol. 78, no. 6, pp. 2039-2042, 2012.

[73] A. K. Neu, M. Månsson, L. Gram, and M. J. Prol-García, "Toxicity of bioactive and probiotic marine bacteria and their secondary metabolites in Artemia sp. and Caenorhabditis elegans as eukaryotic model organisms," Applied and Environmental Microbiology, vol. 80, no. 1, pp. 146-153, 2014.

[74] S. Matthijs, C. Vander Wauven, B. Cornu et al., "Antimicrobial properties of Pseudomonas strains producing the antibiotic mupirocin," Research in Microbiology, vol. 165, no. 8, pp. 695-704, 2014.

[75] A. M. Fathalla, A. M. A. E.-A. Samy, A. B. Metwaly, and E. M. Ramadan, "Characterization of antifungal metabolites from antagonistic fluorescent pseudomonads," Journal of Applied Plant Protection, vol. 4, pp. 13-21, 2015.

[76] P. Cos, A. J. Vlietinck, D. V. Berghe, and L. Maes, "Antiinfective potential of natural products: how to develop a stronger in vitro "proof-of-concept," Journal of Ethnopharmacology, vol. 106, no. 3, pp. 290-302, 2006.

[77] S. Zonyane, N. P. Makunga, and S. F. Van Vuuren, The Antimicrobial Interactions of Agathosma crenulata, Dodonaea viscosa and Eucalyptus globulus Combination and their Chemical Profiling, Stellenbosch University, Stellenbosch, South Africa, 2013.

[78] J. K. Dzotam, I. K. Simo, G. Bitchagno et al., "In vitro antibacterial and antibiotic modifying activity of crude extract, fractions and $3^{\prime}, 4^{\prime}, 7$-trihydroxyflavone from Myristica fragrans Houtt against MDR gram-negative enteric bacteria," BMC Complementary and Alternative Medicine, vol. 18, no. 1, pp. 1-9, 2018.

[79] T. Pusztahelyi, I. J. Holb, and I. N. Pócsi, "Secondary metabolites in fungus-plant interactions," Frontiers in Plant Science, vol. 6, no. 6, pp. 1-23, Article ID 573, 2015.

[80] M. J. Ek-Ramos, R. Gomez-Flores, A. A. Orozco-Flores, C. Rodríguez-Padilla, G. González-Ochoa, and P. TamezGuerra, "Bioactive products from plant-endophytic grampositive bacteria," Frontiers in Microbiology, vol. 10, pp. 1-12, Article ID 463, 2019.

[81] V. Kumar, S. Rai, and P. Gaur, "Endophytic fungi: novel sources of anticancer molecules," Advances in Endophytic Research, Springer, Berlin, Germany, 2014.

[82] C. W. Fennell and J. van Staden, "Crinum species in traditional and modern medicine," Journal of Ethnopharmacology, vol. 78, no. 1, pp. 15-26, 2001.

[83] J. J. Nair and J. van Staden, "Pharmacological and toxicological insights to the South African Amaryllidaceae," Food and Chemical Toxicology, vol. 62, pp. 262-275, 2013.
[84] A. Maroyi, "Ethnobotanical, phytochemical and pharmacological properties of Crinum bulbispermum (Burm f) Milne-Redh and Schweick (Amaryllidaceae)," Tropical Journal of Pharmaceutical Research, vol. 15, no. 11, pp. 2497-2506, 2016.

[85] U. T. Ferdous, M. Shishir, M. A. Shishir, S. N. Khan, and M. M. Hoq, "Bacillus spp.: attractive sources of anti-cancer and anti-proliferative biomolecules," Microbial Bioactives, vol. 1, no. 1, pp. E033-E045, 2018.

[86] H. Gross and J. E. Loper, "Genomics of secondary metabolite production by Pseudomonas spp." Natural Product Reports, vol. 26, no. 11, pp. 1408-1446, 2009.

[87] C. F. Michelsen, H. Jensen, V. J. Venditto, R. C. Hennessy, and P. Stougaard, "Bioactivities by a crude extract from the Greenlandic Pseudomonas sp. In5 involves the nonribosomal peptides, nunamycin and nunapeptin," PeerJ, vol. 3, Article ID e1476, 2015.

[88] M. H. Selim, E.-Z. Karm Eldin, M. M. Saad, E.-S. E. Mostafa, Y. H. Shetia, and A. A. H. Anise, "Purification, characterization of L-methioninase from Candida tropicalis, and its application as an anticancer," Biotechnology Research International, vol. 2015, Article ID 173140, 10 pages, 2015.

[89] M. Selim, H. Elshikh, M. Saad, E. Mostafa, and M. Mahmoud, "Purification and characterization of a novel thermo stable L-methioninase from Streptomyces sp. DMMMH4 and its evaluation for anticancer activity," Journal of Applied Pharmaceutical Science, vol. 6, no. 7, pp. 53-60, 2016.

[90] T. Yoshioka, T. Wada, N. Uchida et al., “Anticancer efficacy in vivo and in vitro, synergy with 5-fluorouracil, and safety of recombinant methioninase," Cancer Research, vol. 58, no. 12, pp. 2583-2587, 1998.

[91] M. J. Fiolka, K. Lewtak, J. Rzymowska et al., "Antifungal and anticancer effects of a polysaccharide-protein complex from the gut bacterium Raoultella ornithinolytica isolated from the earthworm Dendrobaena veneta," Pathogens and Disease, vol. 69, no. 1, pp. 49-61, 2013.

[92] M. J. Fiołka, K. Grzywnowicz, J. Rzymowska et al., "Antitumour and apoptotic effects of a novel tris-peptide complex obtained after isolation of Raoultella ornithinolytica extracellular metabolites," Journal of Applied Microbiology, vol. 118, no. 6, pp. 1357-1369, 2015.

[93] P. Chikezie, C. Ibegbulem, and F. Mbagwu, "Medicinal \& aromatic plants medicinal potentials and toxicity concerns of bioactive principles," Medicinal \& Aromatic Plants, vol. 4, no. 3, pp. 1-15, 2015.

[94] P. Amoa Onguéné, F. Ntie-Kang, L. Lifongo, J. Ndom, W. Sippl, and L. Mbaze, "The potential of anti-malarial compounds derived from African medicinal plants, part I: a pharmacological evaluation of alkaloids and terpenoids," Malaria Journal, vol. 12, no. 1, pp. 449-525, 2013.

[95] M. Khalifa, E. Attia, J. Fahim, and M. Kamel, "An overview on the chemical and biological aspects of lycorine alkaloid," Journal of Advanced Biomedical and Pharmaceutical Sciences, vol. 1, no. 2, pp. 41-49, 2018.

[96] S. E. Kintzios and M. G. Barberaki, Plants that Fight Cancer, CRC Press, Washington, DC, USA, 2004.

[97] A. Evidente and A. Kornienko, "Anticancer evaluation of structurally diverse Amaryllidaceae alkaloids and their synthetic derivatives," Phytochemistry Reviews, vol. 8, no. 2, pp. 449-459, 2009.

[98] J. J. Nair and J. Van Staden, "Traditional usage, phytochemistry and pharmacology of the South African medicinal plant Boophone disticha (L.f.) Herb. (Amaryllidaceae)," 
Journal of Ethnopharmacology, vol. 151, no. 1, pp. 12-26, 2014.

[99] A. Jain, S. Choubev, P. K. Singour, H. Rajak, and R. S. Pawar, "Sida cordifolia (Linn.) - an overview," Journal of Applied Pharmaceutical Science, vol. 1, no. 2, pp. 23-31, 2011.

[100] V. J. Brueton, Trade in Commonly Used Medicinal Bulbs: Value and Ecological Implications, University of the Witwatersrand, Johannesburg, South Africa, 2013.

[101] K. J. S. Farias, P. R. L. Machado, R. F. de Almeida Júnior, and B. A. Lopes da Fonseca, "Brefeldin A and Cytochalasin B reduce dengue virus replication in cell cultures but do not protect mice against viral challenge," Access Microbiology, vol. 1, no. 6, pp. 1-8, 2019.

[102] S.-M. Paek, "Recent synthesis and discovery of Brefeldin A analogs," Marine Drugs, vol. 16, no. 4, pp. 133-215, 2018.

[103] G. A. Strobel, "Endophytes as sources of bioactive products," Microbes and Infection, vol. 5, no. 6, pp. 535-544, 2003.

[104] J. Ludwig-Müller, "Plants and endophytes: equal partners in secondary metabolite production?" Biotechnology Letters, vol. 37, no. 7, pp. 1325-1334, 2015.

[105] E. C. Chutulo and R. K. Chalannavar, "Endophytic mycoflora and their bioactive compounds from Azadirachta indica: a comprehensive review," Journal of Fungi, vol. 4, no. 2, pp. 42-12, 2018.

[106] T. Aniszewski, Alkaloids-Secrets of Life Alkaloid Chemistry, Biological Significance, Applications and Ecological rolE, Elsevier Science, Amsterdam, Netherlands, 2007.

[107] S. M. Muema, Phytochemical and Anthelmintic Study of the Root Bark of Teclea trichocarpa, Engl. (Rutaceae), University of Nairobi, Nairobi, Kenya, 2013.

[108] J. J. Nair, A. K. Machocho, W. E. Campbell et al., "Alkaloids from Crinum macowanii," Phytochemistry, vol. 54, no. 8, pp. 945-950, 2000.

[109] E. E. Elgorashi, S. E. Drewes, and J. van Staden, "Organ-toorgan and seasonal variation in alkaloids from Crinum macowanii," Fitoterapia, vol. 73, no. 6, pp. 490-495, 2002.

[110] J. D. Phillipson, S. R. Hemingway, N. G. Bisset, P. J. Houghton, and E. J. Shellard, "Angustine and related alkaloids from species of Mitragyna, nauclea, uncaria, and Strychnos," Phytochemistry, vol. 13, no. 6, pp. 973-978, 1974.

[111] J. P. De Andrade, Y. Guo, M. Font-Bardia et al., "Crininetype alkaloids from Hippeastrum aulicum and H. calyptratum," Phytochemistry, vol. 103, pp. 188-195, 2014.

[112] Y. Guo, Research on the Alkaloids of Amaryllidaceae Plants: Genera Lycoris and Hippeastrum, Universitat de Barcelona, Barcelona, Spain, 2015.

[113] M. He, C. Qu, O. Gao, X. Hu, and X. Hong, "Biological and pharmacological activities of Amaryllidaceae alkaloids," RSC Advances, vol. 5, no. 21, pp. 16562-16574, 2015.

[114] N. T. N. Tram, T. V. Titorenkova, S. V. Bankova, N. V. Handjieva, and S. S. Popov, "Crinum L. Amaryllidaceae," Fitoterapia, vol. 73, pp. 183-208, 2002.

[115] J. J. Nair, J. Bastida, C. Codina, F. Viladomat, and J. van Staden, "ChemInform abstract: alkaloids of the South African Amaryllidaceae: a review," ChemInform, vol. 45, no. 30, p. no, 2014.

[116] A. R. Ndhlala, B. Ncube, A. Okem, R. B. Mulaudzi, and J. Van Staden, "Toxicology of some important medicinal plants in southern Africa," Food and Chemical Toxicology, vol. 62, pp. 609-621, 2013.

[117] S. Ahmad, M. Garg, M. Ali, M. Singh, T. Athar, and S. H. Ansari, "A phyto-pharmacological overview on Adhatoda zeylanica Medic. syn. A. Vasica (Linn.) Nees," Natural Product Radiance, vol. 8, pp. 549-554, 2009.
[118] J. H. Xue, L. X. Xu, Z.-H. Jiang, and X. Wei, "Quinazoline alkaloids from Streptomyces michiganensis," Chemistry of Natural Compounds, vol. 48, no. 5, pp. 839-841, 2012.

[119] K. Seehafer, F. Rominger, G. Helmchen et al., "Synthesis and biological properties of novel Brefeldin A analogues," Journal of Medicinal Chemistry, vol. 56, no. 14, pp. 5872-5884, 2013.

[120] A. Aires, Phenolics in Foods: Extraction, Analysis and Measurements, Intech Open, London, UK, 2012.

[121] S. Moco, R. J. Bino, O. Vorst et al., "A liquid chromatography-mass spectrometry-based metabolome database for tomato," Plant Physiology, vol. 141, no. 4, pp. 1205-1218, 2006.

[122] S. Naz, H. Gallart-Ayala, S. N. Reinke et al., "Development of a liquid chromatography-high resolution mass spectrometry metabolomics method with high specificity for metabolite identification using all ion fragmentation acquisition," Analytical Chemistry, vol. 89, no. 15, pp. 7933-7942, 2017.

[123] E. E. Elgorashi, Alkaloids from Three South African Crinum Species, University of Natal Pietermaritzburg, Pietermaritzburg, South Africa, 2000.

[124] Z. Jin and G. Yao, "Amaryllidaceae and Sceletium alkaloids," Natural Product Reports, vol. 36, pp. 1462-1488, 2019.

[125] L. Yang, K.-S. Wen, X. Ruan, Y.-X. Zhao, F. Wei, and Q. Wang, "Response of plant secondary metabolites to environmental factors," Molecules, vol. 23, no. 4, pp. 1-26, Article ID 762, 2018

[126] A. S. Van Wyk and G. Prinsloo, "Medicinal plant harvesting, sustainability and cultivation in South Africa," Biological Conservation, vol. 227, pp. 335-342, 2018.

[127] S. A. Department of Science and Technology, The BioEconomy Strategy Is an Initiative of the Department of Science and Technology, S. A. Department of Science and Technology, Pretoria, South Africa, 2013. 